\title{
PEPPERDINE
}

UNIVERSITY — Pepperdine Dispute Resolution Law Journal

12-1-2007

\section{A Permanent Resolution Mechanism of Cultural Property Disputes}

Maria Granovsky

Follow this and additional works at: https://digitalcommons.pepperdine.edu/drlj

Part of the Dispute Resolution and Arbitration Commons, and the International Law Commons

\section{Recommended Citation \\ Maria Granovsky, A Permanent Resolution Mechanism of Cultural Property Disputes , 8 Pepp. Disp. Resol. L.J. Iss. 1 (2007) \\ Available at: https://digitalcommons.pepperdine.edu/drlj/vol8/iss $1 / 2$}

This Article is brought to you for free and open access by the Caruso School of Law at Pepperdine Digital Commons. It has been accepted for inclusion in Pepperdine Dispute Resolution Law Journal by an authorized editor of Pepperdine Digital Commons. For more information, please contact bailey.berry@pepperdine.edu. 
[Vol. 8: 1, 2007]

\title{
A Permanent Resolution Mechanism of Cultural Property Disputes
}

\author{
By Maria Granovsky ${ }^{\ddagger}$
}

\section{INTRODUCTION}

Disputes regarding cultural property ${ }^{\prime}$ are a common irritant in international relations. These disputes stir great passions because they touch

\footnotetext{
${ }^{\ddagger}$ Dr. Granovsky is an associate with the Intellectual Property Group at Morris, Nichols, Arsht \& Tunnell, L.L.P. in Wilmington, Delaware. Dr. Granovsky received her Ph.D. from the University of Toronto, Toronto, Canada, in 1999 and her J.D. from Georgetown University Law Center, Washington D.C., in 2005. Special thanks to Dr. Cynthia Bouchez of Sterne, Kessler, Goldstein \& Fox, P.L.L.C. and Ms. Claire Ford of Morris Nichols for critical reading of the manuscript. The opinions expressed in this article are Dr. Granovsky's and do not reflect the opinions of Morris Nichols.
}

1. Definitions of cultural property vary. Article I of the 1970 UNESCO Convention on the Means of Prohibiting and Preventing the Illicit Import, Export and Transfer of Ownership of Cultural Property provides the following definition:

[T] he term "cultural property" means property which, on religious or secular grounds, is specifically designated by each State as being of importance for archaeology, prehistory, history, literature, art or science and which belongs to the following categories:

a. Rare collections and specimens of fauna, flora, minerals and anatomy, and objects of palaeontological [sic] interest;

b. property relating to history, including the history of science and technology and military and social history, to the life of national leaders, thinkers, scientists and artists and to events of national importance;

c. products of archaeological excavations (including regular and clandestine) or of archaeological discoveries;

d. elements of artistic or historical monuments or archaeological sites which have been dismembered;

e. antiquities more than one hundred years old, such as inscriptions, coins and engraved seals;

f. objects of ethnological interest;

g. property of artistic interest, such as:

i. pictures, paintings and drawings produced entirely by hand on any support and in any material (excluding industrial designs and manufactured articles decorated by hand);

ii. original works of statuary art and sculpture in any material;

iii. original engravings, prints and lithographs;

iv. original artistic assemblages and montages in any material; 
upon questions of cultural identity, religion, and national history. These passions in turn harden the positions taken by the parties involved, retarding resolution and increasing resentment. Indeed, some such disputes have remained unresolved for decades if not centuries. ${ }^{2}$

Because most cultural property disputes are international, they implicate a variety of legal norms and raise complex choice of law questions, such as conflicting evidentiary standards and statutes of limitations. Therefore, "traditional legal norms are often incapable of addressing the special problems of cultural property." 3

Even when international law can provide a correct legal answer as to the ownership of a specific object, that answer, by its nature, often cannot take into account the political, moral, and ethical climate into which a dispute was born or in which it continues to exist. Therefore, while legally correct, this answer may be deemed illegitimate by one or more of the parties involved, all but guaranteeing that this conflict will continue to simmer or that future relations between the parties will suffer. ${ }^{4}$

Despite the frequency of cultural property disputes, there is currently no permanent and universally acceptable framework for their resolution. Rather, each dispute is approached on an ad hoc basis. ${ }^{5}$ Even though each dispute presents a unique set of circumstances, there is sufficient commonality within the class of such disputes to make it amenable to a standardized, if flexible, system of resolution.

This paper proposes one such possible system. The proposed system would include a new permanent international organization dedicated solely to the settlement of cultural property disputes. Under its auspices, a process would exist to guarantee a binding solution while allowing the parties maximum autonomy in resolving their conflict. Both goals are achieved by

\footnotetext{
h. rare manuscripts and incunabula, old books, documents and publications of special interest (historical, artistic, scientific, literary, etc.) singly or in collections

i. postage, revenue and similar stamps, singly or in collections;

j. archives, including sound, photographic and cinematographic archives;

$k$. articles of furniture more than one hundred years old and old musical instruments.
}

UNESCO, http:/www.unesco.org/culture/laws/1970/html_eng/page2.shtml (last visited Sept. 30, 2007).

2. For a discussion of cultural property disputes generally, see John Henry Merryman, Two Ways of Thinking about Cultural Property, 80 AM. J. INT'L LAW 831 (1986), available at http:/www.asil.org/ajil/v80831.pdf. See also KLUWER LAW INTERNATIONAL, RESOLUTION OF CULTURAL PROPERTY DISPUTES (The Int'l Bureau of the Permanent Court of Arbitration ed., 2004).

3. Tjaco T. van den Hout, Introduction to RESOLUTION OF CULTURAL PROPERTY DISPUTES, supra note 2 , at $\mathrm{XV}$.

4. See id.

5. Id. at XIV. 
[Vol. 8: 1, 2007]

PEPPERDINE DISPUTE RESOLUTION LAW JOURNAL

structuring the process as a series of escalating steps-from negotiation through mediation to arbitration-while building in choice as to the form that each step would take. A hypothetical case study of a current real-life cultural property dispute involving four nations and certain individuals illustrates this system.

\section{Cultural Property Disputes}

Cultural property disputes take multiple forms. ${ }^{6}$ They concern, singly or in combination, questions of ownership, location and stewardship. ${ }^{7}$ Any of these disputes may have added layers of complexity such as violations of export controls or a bona fide purchase somewhere along the chain of possession.

There are disputes over stolen objects, ${ }^{8}$ and objects that were acquired in a manner that is prima facie lawful. ${ }^{9}$ There are disputes over the handling of a cultural heritage of an invaded nation by the invader, ${ }^{10}$ and the handling of cultural property by a government internally. " And then, there are disputes still raging over war-time plunder.

It is important to acknowledge that each dispute is a microcosm of greater interests: a poor country that has become a source of antiquities will not view the dispute in the same manner as a wealthy consumer country where, arguably, there are greater resources available to conserve and preserve these antiquities. Each interest is also shaped by historical considerations such as relations between former colonizers and their colonies and traditional allies and enemies. Nor are the interests of each party fixed from dispute to dispute: Russia, for example, is not only a source country for religious icons, but a consumer country for cultural property gained during World War II, or now bought with its abundant petro-dollars.

6. Katherine Last, Issues of Definition, in RESOLUTION OF CULTURAL PROPERTY DISPUTES, supra note 2 , at $53,65-74$.

7. Id. at 77 .

8. Id. at 66, discussing Autocephalous Greek-Orthodox Church of Cyprus v. Goldberg \& Feldman Fine Arts, Inc., 917 F.2d 278 (7th Cir. 1990) (Byzantine mosaics stolen from a church in Cyprus and purchased by an arts dealer in the duty free zone of the Geneva airport).

9. Id. at 68-69. Examples of such disputes is the case of Gentili di Giuseppe, whose art collection was seized and sold at auction after his family had fled France; and the case of a painting, currently at the Tate Gallery, that was sold by a Jewish World War II refugee to avoid starvation. Id.

10. Id. A recent example of such controversy is the handling and safeguarding of Iraqi antiquities by U.S. forces since the invasion of Iraq in March 2003.

11. For example, the Taliban's destruction of the Buddha statutes of Bamyan. Id. 
A good example of how complex cultural disputes are and how they become so is the one surrounding the Schliemann collection, to which Russia, Germany, Turkey, and Greece lay claim.

\section{A. A Case Study: To whom does the Schliemann Collection belong?}

\section{i. History}

In 1871, Heinrich Schliemann was on a mission to find Troy, the fabled city immortalized in Homer's Iliad and Odyssey. ${ }^{12}$ His search focused on Hisarlik, a site on the Trojan plane (also known as the Troad), located in Turkey. That site was recommended to him by Frank Calvert, a British diplomat and an avid amateur archaeologist, who spent the majority of his life on the Troad and who owned part of the site at Hisarlik. In return for the right to excavate on his lands, Calvert asked for half of the objects the Schliemann would find there. ${ }^{13}$

During the excavation, Schliemann inadvertently dug deeper than the stratum of the late bronze age (where Troy would have been expected to be) to find a city of a much earlier period. There he found multiple artifacts, including many intricate pieces of gold jewelry. Believing that he had found Troy, Schliemann dubbed the collection of artifacts "the treasure of Priam" in honor of the Trojan king immortalized by Homer. ${ }^{14}$

Schliemann crated "the treasure of Priam" and smuggled it in its entirety out of Turkey into Greece. In doing so, he violated the terms of his Turkish excavation permit, which required him to hand over a portion of his findings to the state, as well as a ministerial decree prohibiting the removal of any artifacts from Turkey, including Schliemann's rightful share. The Turkish government sued Schliemann in the Greek courts, demanding the return of half of his Troy collection, but not raising the issue of illegal exportation. The suit was settled. ${ }^{15}$

The text of the final settlement is not available, and we are left to rely on Schliemann's claim that Turkey relinquished all rights to the treasure in return for a one-time monetary payment. Events subsequent to the settlement, however, tend to bear out his account. For example, Turkey

12. See Susan Heuck allen, Fnding the Walls of Troy: Frank Calvert and HEINRICH SCHLIEMANN AT HISARLIK (1999), for a history of the excavation of Troy.

13. Id. See also Donald Fyfe Easton, The Excavation of the Trojan Treasures, and Their History up to the Death of Schliemann in 1890, in THE SPOLS OF WAR (Elizabeth Simpson ed., 1997).

14. See AlLEN, supra note 12.

15. Easton, supra note 13, at 197-98. 
[Vol. 8: 1, 2007]

PEPPERDINE DISPUTE RESOLUTION LAW JOURNAL

issued a new permit to Schliemann for his $1878-79$ excavations under terms similar to the original permit. ${ }^{16}$ In addition, although the collection was exhibited openly and notoriously in London and in Berlin from 1878 until 1939 , Turkey made no further attempt to reclaim it until the present. ${ }^{17}$

Schliemann eventually made a gift of the collection to the German people. $^{18}$ During World War II, Berlin's Museum für Vor-ünd Fruhgeschichte, the permanent exhibitor of the collection since 1881, took several steps to protect it. ${ }^{19}$ Days before the war broke out, the collection was transferred to the ground floor of the museum, inventoried, and crated. It was later transferred to the deep vault of the Prussian State Bank, and again to bunkers specifically designed to protect Berlin's cultural treasures where it remained for the duration of the war. ${ }^{20}$

In 1945, as the allies were closing in on Berlin, the Western allies agreed to hold back and allow the Red Army to enter Berlin first. ${ }^{21}$ This arrangement allowed the Soviets to collect and ship vast repositories of artworks, antiquities, archives, and libraries back to the Soviet Union with impunity. ${ }^{22}$ Among these treasures was the Schliemann collection, which was removed from Germany in May or June of 1945, after the war had ended. ${ }^{23}$

\section{ii. The Current Status of the Collection}

The fate of the collection was not officially verified until 1991, when Soviet museum curators acknowledged that the Soviet Union still possessed cultural property repositories taken from Germany at the end of World War

16. Id.

17. Id.

18. Id.

19. See Klaus Goldmann, The Trojan Treasures in Berlin: The Disappearance and Search for the Objects after World War II, in THE SPOILS OF WAR 200, 200-02 (Elizabeth Simpson ed., 1997).

20. Id. at 200. These bunkers were constructed of steel and concrete and were optimally airconditioned. Throughout the war, the museum collections stored in these bunkers suffered only minor damage and losses, even though the bunkers were subjected to continual air raids. Id. at 201 .

21. See Stephen E. Ambrose, EISENhower and BERLin 1945: THE DECISION to Halt at THE ELBE 66-67, 88-89 (2000).

22. See Andrea Gattini, Restitution by Russia of Works of Art Removed from German Territory at the End of the Second World War, 7 EUR. J. INT'L L. 67, 67-68 (1996).

23. See ALLEN, supra note 12. The removal of cultural property was coordinated by the Soviet Trophy Commission. The Trophy Commission was established by express orders from Joseph Stalin, and its mission was the removal of European art collections and state and private libraries in reparation for the suffering inflicted by the Nazis on the Soviet people. Id. 
II. ${ }^{24}$ This revelation touched off a new round of international soul-searching regarding the status and appropriate disposition of cultural property looted and pillaged in wartime. ${ }^{25}$

Russia, as the successor of the Soviet Union, maintains that it holds legal title to the Schliemann collection on the basis of the following four legal theories. ${ }^{26}$ First, citing the act of state doctrine, Russia asserts that upon victory, the Soviet Union became the successor to the German state, thereby becoming the rightful owner of the Schliemann collection. ${ }^{27}$ Alternatively, Russia cites the doctrine of prescription, arguing that the Soviet Union rescued the Schliemann collection for all mankind and that the passage of time has made the Schliemann collection Russian cultural patrimony, much like the passage of time has made the Elgin Marbles British cultural patrimony. ${ }^{28}$ Russia further supports its position by the principle of repose, which holds that the status quo should be upheld. ${ }^{29}$ The status quo, of course, would see the Schliemann collection remain where it is. ${ }^{30}$ Finally, Russia also argues that, as a victorious power, it is allowed legitimate war reparations for the barbarity of the Germans towards the Soviet people and for the loss of its own cultural property, and that the taking of the Schliemann collection constitutes nothing more than such reparations. ${ }^{31}$

Germany counters that Russia has agreed to repatriate the Schliemann collection by concluding two bilateral treaties with Germany that relate to the return of cultural property. It also argues that Russia is obligated to repatriate the collection by customary international law and by the Hague

24. See S. Shawn Stephens, The Hermitage and Pushkin Exhibits: An Analysis of the Ownership Rights to Cultural Properties Removed from Occupied Germany, 18 HouS. J. INT'L L. 59, 61 (1995). See also Stephen K. Urice, Claims to Ownership of the Trojan Treasures, in THE SPOILS OF WAR (Elizabeth Simpson ed., 1997).

25. See Stephens, supra note 24 , at 60.

26. See id. at 93 .

27. See Stephens, supra note 24 , at $93-96$.

28. See id. at $96-98$.

29. See id. at 98.

30. See id.

31. See Mark Boguslavsky, Legal Aspects of the Russian Position in Regard to the Return of Cultural Property, in THE SPOILS OF WAR 188-89 (Elizabeth Simpson ed., 1997); Stephens, supra note 24, at 98-105. In a May 18, 2006 interview with Interfax, Irina Antonova, the General Director of the Pushkin Museum of Fine Arts, where the Schliemann collection is currently housed, stated that the collection "was taken from Germany to the USSR as compensatory restitution for losses suffered by the Soviet Union during WWII" and that it is now "federal property and an inseparable part of the Russian Federation's museum collection." Interview with Irina Antonova, General Director, Pushkin Museum of Fine Arts, in St. Petersburg, Russia (May 18, 2006). 
[Vol. 8: 1, 2007]

PEPPERDINE DISPUTE RESOLUTION LAW JOURNAL

Convention of 1907 , to which it is a signatory. ${ }^{32}$, As an indication of its belief in the strength of its position, Germany has stated that it is willing to resolve this dispute in the International Court of Justice ("ICJ") or through arbitration. ${ }^{33}$

In addition to Germany and Russia, both Turkey and Greece lay claim to the collection on the basis of their historical ties to it. ${ }^{34}$ Both countries view this dispute from the point of view of source countries for antiquities. Both have made great efforts to protect their heritage by limiting exportation and pursuing the return of antiquities already exported. Turkey claims that the artifacts removed by Schliemann (both the collection now in Russia and other artifacts dispersed in some forty other collections found throughout the world) should be reunified and returned to the original excavation site. ${ }^{35}$ Turkey argues that humanity's effort to study ancient civilizations would be best advanced by studying the objects in situ. ${ }^{36}$ Greece bases its claim on it being the historical and cultural heir of the ancient Greeks. ${ }^{37}$

Viewing these competing claims through the prism of international law, there is little doubt that Germany is the rightful owner of the Schliemann collection. As an initial matter, the Turkish and Greek claims appear to have scant legal support. First, the Turkish claim is likely barred by the settlement with Schliemann in 1874 and the subsequent failure to state a further claim even though the collection was publicly exhibited. The public exhibition will also act to bar the Greek claims. And even if not so barred,

32. A legal dispute should be resolved in accordance with the law contemporaneous with it. Island of Palmas (Neth. v. USA), 2 R.I.A.A. 829, 845 (Per. Ct. Arb. 1928). Thus, although international law regarding cultural property has developed substantially since 1945, these new developments are immaterial for the interpretation of the dispute regarding Schliemann's collection.

33. See Urice, supra note 20 , at 205. Germany has also countered the Russian arguments that are based on the act of state doctrine and on the doctrine of prescription. See Stephens, supra note 24. Germany asserts that its occupation by the Allies did not result in the loss of its sovereignty and that, therefore, the act of state doctrine is not applicable. See id. Germany further points out that the bunker in which the Schliemann collection was housed at the end of the war was located in the British Sector where, by definition, the Soviet Union did not govern. See id. Finally, Germany disputes Russia's argument that the Soviet Union acted to save the collection by removing it from Germany: because hostilities had already ended, the collection was no longer in danger. See id.

34. In addition to the nation-states with claims to the collection, it has been reported that Frank Calvert's American and British heirs may sue for the return of certain objects from Schliemann's collection because these objects appear to have come from Calvert's land. See Susan Heuck Allen, Calvert's Heirs Claim Schliemann Treasure, ARCHAEOLOGY, Jan.-Feb. 1996, at 26-7.

35. See Stephens, supra note 24.

36. See id.

37. See Easton, supra note 13, at 197-98. 
the Greek claim is weakened by the fact that the artifacts were not found on Greek soil. ${ }^{38}$ Thus, even though both Turkish and Greek claims are not morally or ethically frivolous, they will be given no consideration under a framework that is not designed to account for anything other than the legal dimension of the dispute.

The claims of Russia and Germany cannot be so easily dismissed. Russia and Germany have signed two bilateral treaties regarding repatriation of cultural property. ${ }^{39}$ The 1990 Treaty on Good-Neighborliness, Partnership and Cooperation between Germany and the Soviet Union provides that the parties "agree that lost or unlawfully transferred art treasures which are located in their territory will be returned to their owners or their successors."40 The 1992 German-Russian Agreement on Cultural Cooperation provides that the contracting parties "agree that lost or unlawfully transferred cultural property which is located in their sovereign territory will be returned to its owners or their successors." 41 Russia has insisted that both clauses relate to a comprehensive settlement of all cultural patrimony disputes between the two nations. Nowhere in the treaties, however, are the terms of these clauses defined in a manner consistent with Russia's interpretation. ${ }^{42}$

The treaties instead should be evaluated in accordance with the Vienna Convention on the Law of Treaties, to which both Germany and Russia are signatories. The Vienna Convention holds that "[e]very treaty in force is binding upon the parties to it and must be performed by them in good

38. Calvert's heirs are faced with additional hurdles. As an initial matter, the agreement between Schliemann and Calvert called for a division of the artifacts found on Calvert's land. Yet, it is well documented that Schliemann has found at least some of the artifacts in areas that did not belong to Calvert. This, coupled with the lack of documentation as to the exact axes that are now in the Schliemann collection may well have been Schliemann's rightful share. An added complication is the fact that in civil code countries, such as Germany, a thief can pass good title. See Steven F. Grover, Note, The Need for Civil-Law Nations to Adopt Discovery Rules in Art Replevin Action: $A$ Comparative Study, 70 TEX. L. REV. 1431, 1432 (1992). Thus, regardless of whatever questions there may be about Schliemann's rights to the collection, his gift of it to the Museum für Vor- ünd Fruhgeschichte created good title. See id.

39. Stephan Wilske, International Law and the Spoils of War: To the Victor the Right of Spoils?, 3 UCLA J. INT'L \& FOREIGN AFF. 223, 270 (1998).

40. Treaty Between the Federal Republic of Germany and the Union of Soviet Socialist Republics on Good-Neighborliness, Partnership and Cooperation, reprinted in THE SPOILS OF WAR 305 (Elizabeth Simpson ed., 1997); see also Wilske, supra note 40, at 270.

41. Agreement Between the Government of the Federal Republic of Germany and the Government of the Russian Federation on Cultural Cooperation, reprinted in THE SPOILS OF WAR 307 (Elizabeth Simpson ed., 1997); see also Wilske, supra note 40, at 271.

42. Acting on its understanding of the treaties, Germany has repatriated (and Russia has accepted) works of art as they were discovered without waiting for a comprehensive settlement. See Wilske, supra note 40. 
[Vol. 8: 1, 2007]

PEPPERDINE DISPUTE RESOLUTION LAW JOURNAL

faith." ${ }^{43}$ Further, it mandates that "[a] State is obliged to refrain from acts which would defeat the object and purpose of a treaty ...,"44 The Vienna Convention also provides rules for interpreting treaties: "A treaty shall be interpreted in good faith in accordance with the ordinary meaning to be given to the terms of the treaty in their context and in the light of its object and purpose." ${ }^{45}$ The plain language of the treaties between Russia and Germany supports Germany's contention that Russia has committed itself to repatriating the Schliemann collection. Russia's belated insistence that it is not obligated under the treaties, until and unless comprehensive settlement is reached, violates its obligation under the Vienna Convention to deal in good faith.

Germany's position is further supported by customary international law. Customary international law arises out of consistent and widely practiced customs adopted by states when such compliance is coupled with a sense of legal obligation. ${ }^{46}$ While victory in battle was long regarded as carrying with it the right to the spoils, ${ }^{47}$ treaties providing for some limited return of cultural property to its rightful owners upon cessation of hostilities were concluded as early as the $17^{\text {th }}$ century. ${ }^{48}$ The growing respect for an enemy's cultural property rights is evident in the terms of the French Surrender after Napoleon's defeat. ${ }^{49}$ The Conference of Vienna, following the principle of restitution in integrum ("restitution to the previous condition"), ${ }^{50}$ forced France to return the cultural property that it plundered during the Napoleonic Wars. ${ }^{51}$ By 1863, when the Lieber Code first codified the rules of war, the protected status of cultural property was widely acknowledged. ${ }^{52}$

Further, as a signatory to the Hague Convention of 1907, Russia has expressly agreed that it would be unlawful to "destroy or seize the enemy's

43. Vienna Convention on the Law of Treaties, art. 26, May 23, 1969, 1155 U.N.T.S. 331, available at $\mathrm{http}: / /$ untreaty.un.org/ilc/texts/instruments/english/conventions/1_1_1969.pdf.

44. Id. at art. 18.

45. Id. at art. 31

46. RESTATEMENT (THIRD) OF THE FOREIGN RELATIONS LAW § 102(2) (1987).

47. The seizure of cultural property from the enemy was done as much to enrich and honor the victor as to humiliate the vanquished. Indeed, it was the custom both in ancient Greece and in ancient Rome to plunder and take away artworks. See Wilske, supra note 40, at 241-42.

48. Id. at 243 .

49. Id. at 246 .

50. Id. at 257

51. Id.

52. Id. at $246-49$. 
property, unless such destruction or seizure be imperatively demanded by the necessities of war." 53 Because the Schliemann collection was taken after cessation of hostilities between the Allies and Germany, its removal clearly violated the Hague Convention.

Yet, in the current environment, even though Germany has the strongest legal claim to the collection, it is far from certain that Russia will relinquish its rights and repatriate it to Germany for two reasons. First, Russian emotions still run high over the destruction and looting of their own cultural property, not to mention the enormous human cost, wrought by the Nazi invasion. ${ }^{54}$ Any discussion regarding the repatriation of German cultural property is met with a storm of indignation, as many consider the war booty taken from Germany at the end of World War II to be but a small measure of restitution for Germany's war crimes. ${ }^{55}$ Second, there is very little pressure that can be brought to bear on Russia to return German cultural property, especially in view of Russia's current position as a dominant supplier of oil to all of Western Europe.

Russia's present strength brings up an important issue: as is common in cultural property disputes, the nation states that are parties to this dispute are bound by an intricate web of relations that has developed since the end of World War II. For example,

53. Id. at 249. Convention (IV) Respecting the Laws and Customs of War on Land, Oct. 18, 1907, 36 Stat. 2277. The Convention also prohibits pillaging, including the taking of private property.

54. See Wilske, supra note 40 , at 227.

55. Id. at 257-58. 
[Vol. 8: 1, 2007]

PEPPERDINE DISPUTE RESOLUTION LAW JOURNAL

(a) Germany is currently Russia's biggest trading partner and its largest foreign investor; ${ }^{56}$

(b) Turkey is striving to gain entry into the European Union, of which Germany and Greece are members; ${ }^{57}$

(c) Millions of Turks live in Germany as guest-workers; their integration into German society has been slow to non-existent, partly due to the difficulties Turkish workers face in obtaining German citizenship; ${ }^{58}$

(d) Turkey, Greece and Germany are members of NATO; ${ }^{59}$ and

(e) Turkey and Greece are overcoming generations of simmering ethnic and religious conflicts. ${ }^{60}$

\section{A Proposed System For the Resolution of CUltural Property DISPUTES}

A growing body of research suggests that the parties' degree of satisfaction with the outcome of a dispute is directly correlated with the

56. See Mark A. Smith, The Russian, German and Polish Triangle, in RUSSIAN SERIES (Conflict Studies Research Centre eds., 2005), available at www.defac.ac.uk/colleges/csrc/ document-listings/russian/05\%2861\%29 MAS.pdf.

57. See Maureen Freely, $A$ Nation in Search of an Identity, NEw STATESMAN, Nov. 22, 2004, at 31 .

58. See Hannah Cleaver, Our Turkish Workers Mistake, by Schmidt, THE DAILY TELEGRAPH (London) Nov. 25, 2004 at 18, available at http://www.telegraph.co.uk/news/main.jhtml? xml= /news/2004/11/25/wturk25.xml.

59. See North Atlantic Treaty Organization, NATO Member Countries, http://www.nato.int/structur/countries.htm (last visited Oct. 5, 2007).

60. See Warren Hoge, Cyprus Greeks and Turks Agree on Plan to End 40-Year Conflict, N.Y. TIMES, Feb. 14, 2004, at Al. 
degree of autonomy that the parties have in settling the dispute. ${ }^{61}$ In a traditional adversarial system, where there is necessarily a winner and a loser, the degree of dissatisfaction, for at least one of the parties, is quite high. In contrast, a negotiation process often leads to an expansion of the parties' options, allowing the parties to reach a non-zero-sum outcome that would allow all parties to buy in. ${ }^{62}$

Alternative dispute resolution processes are being successfully applied to complex intra and international disputes. The Truth and Reconciliation Commission in South Africa, and work in Rwanda, Ireland, and former Yugoslavia, to name but a few, are recent examples of non-adjudicatory processes for conflict resolution. Each of these processes is successful partly because it is molded to fit the specific conflict and partly because it looks to a holistic solution, rather than the merely legal one.

A successful dispute resolution mechanism for cultural property disputes should be designed to take into account the following considerations:

(a) Buy-in from the parties. The resolution of this dispute should be seen as legitimate by all of the parties. Otherwise, it is likely that the parties would continue to wrangle over the Schliemann collection, or that the parties will try to compensate for their disappointment through hardening positions in future disputes. As discussed above, buy-in is directly correlated with perceived party autonomy; therefore, a negotiated settlement is preferable to an imposed one.

(b) Doing no harm to future relations among the parties, and possibly even strengthening these relations, so that the parties may resolve other conflicts with greater ease.

(c) Political cover. International obligations shared by multiple nations have been shown to provide effective cover for actions that otherwise would be politically untenable domestically. ${ }^{63}$ Fostering a similar sense of binding obligation through a treaty

\footnotetext{
${ }^{61}$ See Cathy A. Costantino \& Christina Sickles Merchant, Designing Conflict MANAGEMENT SYSTEMS (1996), and CARRIE MENKEL-MEADOW ET AL., DisPUTE RESOlution: BEYOND THE ADVERSARIAL MODEL (2005), for a discussion of alternative dispute resolution generally.

62. See id.
} 
[Vol. 8: 1, 2007]

PEPPERDINE DISPUTE RESOLUTION LAW JOURNAL

that establishes the dispute resolution system may help a party take domestically-unpopular actions, especially if the system is viewed as even-handed and able to help that same party to recover its own cultural property.

Reliance on these principles in designing a dispute resolution system yields the following model:

The proposal first entails a negotiated treaty among member states. This treaty should set out threshold criteria for the disputes to be settled by this mechanism (e.g., should stewardship disputes be addressed in this forum?); the make-up of the permanent secretariat that will administer the dispute resolution; whether or not member states can lodge a complaint on behalf of individual citizens; and any mechanisms, such as economic sanctions, to enforce compliance with the resulting settlement of the dispute. Once a treaty is in force, a permanent secretariat is appointed and a roster of technical experts is created.

A member state initiates proceedings by notifying the secretariat and the opposing party (or parties) of its claim. A certification by the secretariat that the claim meets the threshold criteria set forth in the treaty results in the suspension of all litigation involving the cultural property in question. The secretariat notifies all member states of the claim and the notification starts a predetermined period during which any member state can register claims relating to the object(s) in question. If a member state fails to register such a claim during this period, it is permanently barred from raising the claim again, unless new and material information, as determined by the secretariat, becomes available at a later date. This strict limitation is intended to encourage a comprehensive and permanent settlement of a given dispute.

The parties are allowed a predetermined length of time to negotiate a settlement. Alternatively, the parties can jointly certify that they would prefer to forgo the negotiation stage and proceed to mediation. Upon such certification, the secretariat appoints the mediators and a panel of relevant experts who are tasked with reporting on the technical, legal, historic, and diplomatic aspects of the dispute. The reports are distributed to the parties and to the mediators.

63. An example of this is the participation of both Turkey and Greece in NATO's campaign in Bosnia. Despite historic allegiances to different warring factions in that conflict, the governments of both Greece and Turkey were able to withstand political pressures domestically, and support NATO's mission, by citing their obligations under the NATO charter. See, e.g., What is NATO? Europe's Glue, Not Kremlin's Foe, N.Y. TiMES, May 16, 1997, at Al4. 
The mediators have free reign as to the structure of the mediation. In designing the mediation process, however, they should seek input from the parties and incorporate the parties' wishes if practicable. The role of the mediators is to help the parties negotiate a settlement, partly by expanding zones of possible agreement. In that regard, the parties should be encouraged to consider the particular dispute in the broader context of their relations.

The mediation round is also of a predetermined duration. If an agreement is not reached during this round, the secretariat appoints a panel of arbitrators who are charged with issuing an award. In reaching their decision, the arbitrators rely on the technical reports prepared for the mediation round, a report by the mediators describing the mediation, and on a single written submission per party that can include supporting documents that a party chooses to produce. The single written submission rule is designed to streamline the process and to avoid any discrepancies in discovery or briefing procedures among the parties. In contrast to the role of the mediators, who are tasked with exploring settlement options outside of the immediate dispute, the arbitrators may only issue an award relating to the objects in dispute and to monetary compensation. The treaty initially negotiated among the member states may add further limitations on the process by which the arbitrators reach their decision; for example, the treaty may state that the award must be based solely on legal considerations in keeping with specific treaties or conventions.

The arbitrators prepare an award, but do not publish it. The parties are given an opportunity to either have the award published or to go back to a round of mediation. Unless the parties choose unanimously to have the award published, another round of mediation is undertaken. If this mediation round is unsuccessful, the arbitration award is published and binds all of the parties to the dispute.

In order to encourage the parties to negotiate in good faith, the arbitrators are permitted to take into consideration the behavior of the parties during the entire process. Thus, if a party is perceived to be negotiating in bad faith, for example by requesting the additional round of mediation merely as an exercise in foot-dragging, the arbitrators have the authority to assess punitive monetary damages against the party in addition to as much of the proceeding's costs as they see fit.

This dispute resolution system would allow the parties with claims to the Schliemann collection to consider unorthodox solutions that are agreeable to all. By contrast, no such solutions can be explored by the 
[Vol. 8: 1, 2007]

International Court of Justice or by any other tribunal that is restricted solely to the legal aspects of a dispute. ${ }^{64}$

For example, the parties might resolve to address Turkey's argument that modern archaeological practice emphasizes a global view of excavation sites as a means for studying all aspects of ancient civilization. Today's technology would allow exact replication of the objects for placement at the original site. Such replicas could serve to provide information about the positioning and functionality of these objects, much as models and reconstructions are used in other scientific projects. In addition, the parties might contract to provide free and unfettered access to the objects for scientists and historians wishing to study them, wherever the objects themselves end up and, in recognition of the significance of the artifacts to the histories of the parties, a fund might be set up to provide stipends for Greek, Turkish, German, and Russian scientists for the study of the artifacts and the site. Alternatively, these nation states may choose to sponsor a joint scientific group for such study.

As to the objects themselves, perhaps it would be possible to allow certain duplicative artifacts to remain in Russia while repatriating the remainder of the collection to Germany. Another option would be to exhibit the collection on a permanently rotating schedule between Russia and Germany, or among Russia, Germany, Greece, and Turkey, with the acknowledgement that Germany is its lawful owner, and with a renewed apology from Germany for the destruction of Russian cultural property. In addition, it might be possible to create a revenue sharing arrangement, by which the objects are exhibited in a special pavilion on the grounds of the Berlin museum. The revenue from the exhibition could be shared with Russia as a gesture of reconciliation. Further possible arrangements could include the restitution of the collection to Germany in return for guaranteed exhibitions of German cultural property in Moscow and St. Petersburg. Alternatively, Germany could undertake the restoration of war-damaged Russian palaces and churches in return for the collection. ${ }^{65}$

Another possible solution could be the creation of a special museum, administered by UNESCO, for the display of art and cultural property

64. See Stephens, supra note 24 , at 64 .

65. A similar proposal was made by Wolfgang Eichwede, Models of Restitution (Germany, Russia, Ukraine), in THE SPOILS OF WAR 218-20 (Elizabeth Simpson ed., 1997). See also Irina Titova, Russia to Unveil Restored Amber Room, JOHNSON'S RUSSIA LIST E-MAIL NEWSLETTER, May 13, 2003, available at http://www.cdi.org/russia/johnson/7181-3.cfm. 
displaced during World War II, including the Schliemann collection. ${ }^{66}$ Such a museum could exist either in a fixed, neutral location, or as a permanently traveling exhibition that serves to remind the world of the price exacted by war.

Whatever the outcome, it will be binding and enforceable. In contrast, there is currently no international regime that would force the parties to settle their disputes, nor one that would enforce a settlement if one is reached. As discussed above, there is very little to compel Russia to negotiate the fate of the Schliemann collection in good faith, and therefore, under the present conditions it appears that the ownership of the collection will be disputed for years to come.

\section{CONCLUSION}

A system of dispute resolution that allows maximal autonomy, while threatening an imposed solution, may offer the best chance for a negotiated settlement that would be palatable to all sides. A process for resolving cultural property disputes that is guaranteed to lead to a binding outcome raises the stakes for all participants and forces them to participate in direct and mediated negotiations more purposely, rather than leave the outcome to the arbitrators. This, in tum, raises the probability of reaching a legitimate settlement that all parties can respect.

66. The writer Gunther Grass suggested a museum dedicated to plundered art housed in a building built as a bridge over the river Oder, which marks the boundary between Poland and Germany. See Wikipedia, Günter Grass, available at http://en.wikipedia.org/wiki/Günter_Grass (last visited Oct. 24, 2007). 